American Journal of Agricultural and Biological Sciences 4 (1): 32-38, 2009

ISSN 1557-4989

(C) 2009 Science Publications

\title{
Differential Reaction of Citrus Species in Malaysia to Huanglongbing (HLB) Disease using Grafting Method
}

\author{
${ }^{1}$ Hajivand Shokrollah, ${ }^{1}$ Thohirah Lee Abdullah, ${ }^{2}$ Kamaruzaman Sijam, \\ ${ }^{3}$ Siti Nor Akmar Abdullah and ${ }^{1}$ Nur Ashikin Psyquay Abdullah \\ ${ }^{1}$ Departments of Crop Science, Faculty of Agriculture, University Putra Malaysia, \\ 43400 Serdang, Selangor Darul Ehsan, Malaysia \\ ${ }^{2}$ Department of Plant Protection, Faculty of Agriculture, University Putra Malaysia, \\ 43400 Serdang, Selangor Darul Ehsan, Malaysia \\ ${ }^{3}$ Department of Agro Biotechnology, Faculty of Agriculture, University Putra Malaysia, \\ 43400 Serdang, Selangor Darul Ehsan, Malaysia
}

\begin{abstract}
Problem statement: Huanglongbing (HLB) is a phloem limited disease in citrus caused by a fastidious bacterium called 'Candidatus Liberibacter' found in Africa, Asia and United States of America (USA). HLB can severely reduce vigor and yield or kill all citrus trees within 5 years. There is a need to screen and identify suitable rootstock for propagation of clean plan materials for citrus in the tropics. This study was conducted to detect the presence of HLB on 18 selected citrus species and to categorize the level of infection and susceptibility of citrus species to HLB. Approach: Eighteen citrus species were assessed for susceptibility to HLB by graft transmission from source infection (Citrus reticulata). Results HLB was detected in 15 species 6 months after grafting using PCR test. Conclusion: The species could be categorized in five groups: Severe group (72-58\% severity) which includes $C$. reticulata, $C$. sinensis, $C$. reshni cv. cleopatra, moderate group (50-41\% severity) includes Fortunella sp. cv. Kasturi Chinai, C. macrophylla, C. microcarpa, mild group (25-17\% severity) which included $C$. medica, C. aurantifolia, Citrus sp. (natural biotype), $C$. jambhiri. The tolerant group which did not show any HLB symptoms but tested positive by PCR test includes $C$. aurantium and C. aurantifolia. The resistant groups which include C. grandis cv. Limau Bali, C. hysterix and Citrus sp. cv. Limau Tembikai showed no symptoms and were tested negative for HLB.
\end{abstract}

Key words: Huanglongbing, citrus greening disease, disease severity, citrus rootstock

\section{INTRODUCTION}

Citrus is believed to have originated from the region within Northeast India, South China, Indonesia and Peninsular Malaysia. It is an extremely important crop on a world basis and the total world production of citrus was estimated at over 73 million metric tons ${ }^{[1]}$. In Malaysia, citrus is grown in commercial orchards, backyard orchards and small holdings in various parts of the country. For conservation purposes citrus collections was established, which have notable genetic diversity, particularly of the pummelo and some of the related genera and appear to be fairly well maintained. Some are also observed in areas such as the Taman Negara National Park in Pahang and the Danum Valley in $\mathrm{Sabah}^{[2]}$.

Huanglongbing (HLB), commonly known as citrus greening, is one of the most serious diseases that affect citrus fruit. HLB has destroyed an estimated 60 million trees in Africa and Asia ${ }^{[3-5]}$ and occurs in more than 40 countries including Malaysia ${ }^{[1]}$. In Malaysia HLB was first detected in Cameron Highland in 1990. Survey done by Azizah and Zazali $^{[6]}$ revealed that approximately $70 \%$ of the cultivated area with citrus in Malaysia were affected by HLB disease ${ }^{[6]}$. In separate studies, it was shown that HLB was successfully experimentally transmitted from the infected citrus to periwinkle (Catharanthus roseus) and a non-rutaceous host by means of dodder (Cuscuta campestris) ${ }^{[7]}$. HLB is caused by an uncultured phloem limited bacterium that was first characterized in 1994 with the $16 \mathrm{~S}$ rDNA sequence and classified to be a new genus in the $\alpha$ Proteobacteria subdivision ${ }^{[7,8]}$.

Polymerase Chain Reaction (PCR) for HLB detection was developed in 1996 based on the amplification of $16 \mathrm{SrDNA}$ fragments ${ }^{[9]}$. The pathogen

Corresponding Author: Shokrollah Hajivand and Thohirah Lee Abdullah, Department of Crop Science, Faculty of Agriculture, University Putra Malaysia, 43400 Serdang, Selangor Darul Ehsan, Malaysia Tel: +603-8946 6947 Fax: +603-8943 5973 
of HLB has many isolates in various hosts so far. It cannot be diagnosed easily by conventional procedures such as electron microscopic examination of ultra-thin sections, bioassay on indicator plants and EnzymeLinked Immunosorbent Assay (ELISA) with polyclonal or monoclonal antibodies. However molecular tolls such as PCR are a very effective, simple and sensitive tool for HLB detection ${ }^{[7,8]}$. Therefore this study was conducted to detect the presence of HLB on 18 selected citrus species for rootstock through grafting and to categorize the level of infection and susceptibility of 18 citrus species to HLB in Malaysia.

\section{MATERIALS AND METHODS}

Planting materials: Seeds were obtained from the Malaysian Agricultural Research and Development Institute (MARDI) and the Department of Agriculture in Terengganu, Malaysia. Seeds of 18 citrus rootstocks were sown in seed trays using a soil mixture of soil, peat and sand (2:3:1). The seedlings were transplanted 15-20 days after germination into a $16 \mathrm{~cm}$ diameter pot. The seedlings were ready for grafting when they were $40-50 \mathrm{~cm}$ tall. All experimental plants were grown in an insect proof screen house.

Source inoculums and graft transmission success: Source of HLB inoculums was collected from Citrus reticulate cv. Limau Madu which was obtained from University Putra Malaysia (UPM) and confirmed by PCR test. Infected scions were grafted on 18 citrus species (Table 1). Side grafting method ${ }^{[10]}$ was chosen to ensure high rate of HLB transmission via vector transmission using Diaphorina citri which has vector preference. Terminal shoots of $10 \mathrm{~cm}$ long were randomly collected from trees with typical symptoms.

Table1: Percentage of grafting success of 18 selected citrus species

\begin{tabular}{llll}
\hline Sr. No & Scientific name & Local name & Grafting success (\%) \\
\hline 1 & C. jambhiri & Rough lemon & 80 \\
2 & C. grandis & Limau Bali & 78 \\
3 & C. aurantium & Limau Samur & 75 \\
4 & C. reticulate & Limau madu & 75 \\
5 & C. medica & Limau susu & 70 \\
6 & C. microcarpa & Limau kasturi & 69 \\
7 & C. sinensis & Limau lankat & 68 \\
8 & C. aurantifolia & Limau nipis & 65 \\
9 & Citrus sp. & Limau naga & 65 \\
10 & C. reshni & Cleopatra mandarin & 65 \\
11 & C. aurantifolia & Limau (Mexican lime) & 62 \\
12 & Citrus sp. & *(natural biotype) & 60 \\
13 & C. hysterix & Limau purut & 60 \\
14 & Fortunella sp. & Limau kasturi chini & 58 \\
15 & Citrus sp. & *(natural biotype) & 55 \\
16 & Citrus sp. & *(natural biotype) & 55 \\
17 & C. macrophylla & Machrophylla & 50 \\
18 & Citrus sp. & Limau tembikai & 35 \\
*: Unknown citrus species in Malaysia &
\end{tabular}

Twigs were then kept in the transparent plastic bags and placed in a cool box to maintain their freshness.

Vegetative growth assessment of inoculated citrus seedlings: The seedlings were washed thoroughly rinsed in tap water, followed by distilled water and then dried at $65^{\circ} \mathrm{C}$ for $4-5$ days to measure the total dry weight in inoculated and non inoculated plants. Plant height and stem diameter of non inoculated and inoculated citrus species were measured. Data were collected, analyzed and means were separated using Duncan's Multiple Range Test (DMRT).

Disease severity: Disease severity was determined according to alternative rating scale proposed by Bowen $^{[11]}$ and $\operatorname{Kranzm}^{[12]}$ on infected plants ${ }^{[11,12]}$. Base on the leaf symptoms, the scale includes: $0=$ no symptom, 1 = Mild (blotchy mottling symptoms observed from $1-30 \%$ on seedlings canopy), 2 = Moderate (yellowing symptoms observed from 31$50 \%$ on seedlings canopy), 3 = Severe (blotchy mottling, midrib yellowing and twigs dieback symptoms observed of more than $50 \%$ on seedling canopy).The disease severity was measured using the formula below:

$$
\text { Disease severity }=\frac{\sum(\mathrm{a} \times \mathrm{b})}{\mathrm{N} . \mathrm{Z}} \times 100 \%
$$

Where:

$\Sigma(\mathrm{a} \times \mathrm{b})=$ Sum of the symptomatic plant and their corresponding score scale

$\mathrm{N}=$ Total number of sampled plant

$\mathrm{Z} \quad=$ Highest score scale

DNA extraction of citrus tissues: Leaf samples were collected for evaluation from seedlings which were inoculated by grafting method. DNA extraction from citrus tissues was prepared following the method described by Hung et al. ${ }^{[13]}$. DNA was extracted from HLB-infected tissue using Cetyl Trimethyl Ammonium Bromide (CTAB). The pellets were washed with $70 \%$ ethanol, dried and resuspended in $100 \mu \mathrm{L}$ TE buffer.

Polymerase chain reaction (PCR) conditions, primers and gel electrophoresis: PCR was performed using $25 \mu \mathrm{L}$ of reaction mixture containing $20 \mathrm{mM}$ Tris$\mathrm{HCl}(\mathrm{pH} 8.0), 50 \mathrm{mM} \mathrm{KCl}, 4 \mathrm{mM} \mathrm{MgCl} 2,0.2 \mathrm{mM}$ of dATP, dTTP, dCTP and dGTP, 50 ng forward primer, $50 \mathrm{ng}$ reverse primer, 0.75 units of Taq DNA polymerase and 200 ng genomic DNA. The thermal cycle condition was: 1 cycle at $95^{\circ} \mathrm{C}$ for $2 \min 35$ cycles at $95^{\circ} \mathrm{C}$ for $40 \mathrm{sec}, 60^{\circ} \mathrm{C}$ for $1 \mathrm{~min}$ and $72^{\circ} \mathrm{C} 1 \mathrm{~min}$ then followed 
by a $72^{\circ} \mathrm{C}$ extension for $10 \mathrm{~min}$. Specific primers pair, composed of the forward primer of OI1 (5'-GCG CGT ATG CAA TAC GAG CGG CA-3') and reverse primer of OI2c (5'-GCC TCG CGA CTT CGC AAC CCA T$\left.3^{\prime}\right)$, was used to amplify the $16 \mathrm{~S}$ ribosomal DNA fragment. Amplification of DNA were determined by electrophoresis on 1.2\% agarose gel for about 30-45 min and visualized by ethidium bromide staining ${ }^{[13]}$.

\section{RESULTS}

Graft transmission success: All 18 citrus species were grafted using infected scions of Citrus reticulata. The performance of citrus plants varied in terms of grafting success. Result in Table1, shown the highest grafting success was observed on C. jambhiri, C. grandis, $C$. aurantium and $C$. reticulate and $C$. medica (from 70$80 \%$ ). The scion used for grafting on these rootstocks grew and was normal growing development. Low grafting success was observed on three citrus which are the natural biotypes (Citrus sp.), C. macrophylla and Citrus sp. cv. Limau tembicai (from 35-85\%).

Effects of HLB on vegetative growth: Mean comparison of total dry weight, plant height and stem diameter of none inoculated, inoculated and reduction rate of citrus species were measured six months after inoculation. There were significant difference $(p<0: 05)$ between total dry weights of non inoculated citrus species. The highest total dry weight was observed on C. jambhiri, C. aurantium, C. macrophila than on Citrus sp. cv. Limau Tembiki, Citrus sp. (natural biotype), C. aurantifolia cv. Mexican Lime and Citrus sp. cv. Limau Naga. Plant heights of non-infected citrus seedlings were significantly different on C. jambhiri, C. aurantium, C. macrophila and citrus sp. cv. Coleopatra than on Citrus sp.cv. Limau Tembiki, Citrus sp. (natural biotype) and $C$. aurantifolia cv. Mexican Lime. Stem diameter of citrus species was also significantly different at probability statistic level of $5 \%$. The highest stem diameters were observed on C. jambhiri, C. aurantium and C. aurantifolia than other species such as Citrus sp. (natural biotype) and Citrus sp. cv. Limau Tembiki (Table 2).

In inoculated citrus species, mean comparisons of total dry weight, plant height and stem diameter were significantly different (at $\mathrm{p}<0: 05$ ). Total dry weight, plant height and stem diameter of inoculated citrus species were significantly higher on C. hysterix, C. grandis, C. aurantium and $C$. aurantifolia than on C. reticulate cv. Limau Madu, C. sinensis cv. Limau Lankat, C. microcarpa cv. Limau Kasturi and Citrus sp. (natural biotype) (Table 2). Mean comparisons revealed the highest total dry weight, plant height and stem diameter in non-infected than infected citrus species.

Reduction rate percentages were measured to compare the inoculated and non inoculated citrus species. Reduction rate of total dry weight, plant height and stem diameters on seedlings which showed severe symptoms of HLB were higher than the species which showed less HLB symptom, tolerant or resistance species too. Highest reduction rate of total dry weight, citrus plant height and stem diameter were observed on $C$. reticulata, $C$. sinensis, C. macrophylla and $C$. microcarpa than on $C$. grandis, $C$. hysterix, Citrus sp. cv. Limau tembiki, C. aurantifolia and C. aurantium.

Table 2: Comparison between mean of total dry weight, plant height, stem diameters and reduction rate on inoculated and non inoculated of citrus species six months after inoculation

\begin{tabular}{|c|c|c|c|c|c|c|c|c|c|c|}
\hline \multirow{2}{*}{\multicolumn{2}{|c|}{ Citrus species }} & \multicolumn{3}{|l|}{ Inoculated } & \multicolumn{3}{|c|}{ Non inoculated } & \multicolumn{3}{|c|}{ Reduction rate $(\%)$} \\
\hline & & \multirow[b]{2}{*}{$\begin{array}{l}\text { Total dry } \\
\text { weight (g) }\end{array}$} & \multirow[b]{2}{*}{$\begin{array}{l}\text { Plant Height } \\
(\mathrm{cm})\end{array}$} & \multirow[b]{2}{*}{$\begin{array}{l}\text { Stem diameter } \\
(\mathrm{mm})\end{array}$} & \multirow[b]{2}{*}{$\begin{array}{l}\text { Total dry } \\
\text { weight (g) }\end{array}$} & \multirow[b]{2}{*}{$\begin{array}{l}\text { Plant } \\
\text { Height }\end{array}$} & \multirow[b]{2}{*}{$\begin{array}{l}\text { Stem } \\
\text { diameter }(\mathrm{cm})\end{array}$} & \multirow[b]{2}{*}{$\begin{array}{l}\text { Total dry } \\
\text { weight }(\mathrm{mm})\end{array}$} & \multirow[b]{2}{*}{$\begin{array}{l}\text { Plant } \\
\text { height }\end{array}$} & \multirow[b]{2}{*}{$\begin{array}{l}\text { Stem } \\
\text { diameter }\end{array}$} \\
\hline Scientific name & Local name & & & & & & & & & \\
\hline C. grandis & Limau bali & $71.40 \mathrm{a}$ & $72.8 \mathrm{a}$ & $19.3 \mathrm{a}$ & 76.00def & $74.0 \mathrm{~cd}$ & $19.5 \mathrm{c}$ & 6.05 & 3.00 & 5.00 \\
\hline C. hysterix & Limau purut & $67.50 \mathrm{ab}$ & $68.2 \mathrm{abcd}$ & $17.6 \mathrm{bcd}$ & $71.17 \mathrm{gh}$ & $69.5 \mathrm{ef}$ & $19 \mathrm{~cd}$ & 4.17 & 2.00 & 7.36 \\
\hline C. medica & Limau susu & $65.42 \mathrm{abc}$ & $68.4 \mathrm{abc}$ & $16.7 \mathrm{bcdef}$ & $77.00 \mathrm{bcde}$ & $76.0 \mathrm{bcd}$ & $18 \mathrm{de}$ & 14.28 & 11.60 & 19.14 \\
\hline C. aurantium & Limau samur & $68.40 \mathrm{ab}$ & $69.4 \mathrm{ab}$ & $19.0 \mathrm{a}$ & 79.73ab & $78.5 \mathrm{ab}$ & $23.5 \mathrm{a}$ & 15.03 & 11.16 & 7.22 \\
\hline C. aurantifolia & Limau nipis & $65.20 \mathrm{abc}$ & $69.0 \mathrm{ab}$ & 14.6efgh & $78.10 \mathrm{bcd}$ & 77.0abc & $17.5 \mathrm{e}$ & 16.51 & 10.40 & 16.60 \\
\hline C. macrophila & Macrophila & $62.00 \mathrm{bcd}$ & $64.2 \mathrm{bcdef}$ & $16.0 \mathrm{cdefg}$ & $79.13 \mathrm{abc}$ & $78.0 \mathrm{ab}$ & $20.0 \mathrm{c}$ & 18.38 & 15.00 & 12.00 \\
\hline C. aurantifolia & Mexican lime & 56.80de & $59.0 \mathrm{fg}$ & $18.6 \mathrm{ab}$ & $69.20 \mathrm{hi}$ & $66.5 \mathrm{fg}$ & $21.0 \mathrm{~b}$ & 21.64 & 17.70 & 20.00 \\
\hline Citrus sp. & Limau tembikai & $59.06 \mathrm{cde}$ & $61.2 \mathrm{cdefg}$ & 15.3defgh & $61.00 \mathrm{j}$ & $66.0 \mathrm{~g}$ & $16.5 \mathrm{f}$ & 3.20 & 2.18 & 7.30 \\
\hline C. reshni & Coleopatra mandarin & $58.70 \mathrm{cde}$ & $60.0 \mathrm{fg}$ & $14.0 \mathrm{fgh}$ & $78.07 \mathrm{bcd}$ & $77.3 \mathrm{~d}$ & 18.0de & 17.90 & 11.30 & 11.40 \\
\hline C. jambhiri & Rough lemon & $66.70 \mathrm{ab}$ & 68.0abcde & $19.3 \mathrm{ab}$ & $81.73 \mathrm{a}$ & $80.0 \mathrm{a}$ & $24.0 \mathrm{a}$ & 24.80 & 20.05 & 22.22 \\
\hline Fortunella sp. & Kasturi chini & $55.10 \mathrm{de}$ & $59.5 \mathrm{fg}$ & $15.5 \mathrm{defg}$ & $75.00 \mathrm{ef}$ & $74.0 \mathrm{~cd}$ & $19.5 \mathrm{c}$ & 26.53 & 19.60 & 32.44 \\
\hline Citrus sp. & Limau naga & $56.40 \mathrm{de}$ & 61.0defg & $17.2 \mathrm{bcde}$ & 69.17hi & 69.0efg & $19.5 \mathrm{c}$ & 18.46 & 11.60 & 12.00 \\
\hline Citrus sp. & Limau 3 & $56.60 \mathrm{de}$ & $60.6 \mathrm{fg}$ & 16.6bcdef & $66.50 \mathrm{i}$ & $67.0 \mathrm{efg}$ & $19.5 \mathrm{c}$ & 14.88 & 10.00 & 15.00 \\
\hline Citrus sp. & limau2 & 58.90cde & 61.4cdefg & 14.0fgh & $66.50 \mathrm{i}$ & $66.0 \mathrm{~g}$ & $16.0 \mathrm{f}$ & 11.50 & 7.00 & 12.50 \\
\hline Citrus sp. & limau1 & $58.20 \mathrm{de}$ & $60.8 \mathrm{efg}$ & 15.3defgh & $68.50 \mathrm{hi}$ & 67.0efg & $17.5 \mathrm{e}$ & 15.00 & 11.00 & 12.60 \\
\hline C. microcarpa & Limau kasturi & $54.60 \mathrm{e}$ & $59.6 \mathrm{fg}$ & 15.2 defgh & $75.73 \mathrm{def}$ & $73.5 \mathrm{~d}$ & $19.0 \mathrm{~cd}$ & 27.90 & 18.90 & 18.40 \\
\hline C. sinensis & Limau lankat & $48.32 \mathrm{f}$ & $56.0 \mathrm{gh}$ & $13.2 \mathrm{gh}$ & $76.50 \mathrm{cde}$ & $76.0 \mathrm{bcd}$ & $19.0 \mathrm{~cd}$ & 36.80 & 26.31 & 31.00 \\
\hline C. reticulata & Limau madu & $43.70 \mathrm{f}$ & $50.4 \mathrm{~h}$ & $12.5 \mathrm{~h}$ & $73.50 \mathrm{fg}$ & $70.0 \mathrm{e}$ & 18.0de & 40.50 & 28.00 & 30.00 \\
\hline
\end{tabular}

Means within column followed by the same letters are not significant at $\mathrm{p}=0.05$ 


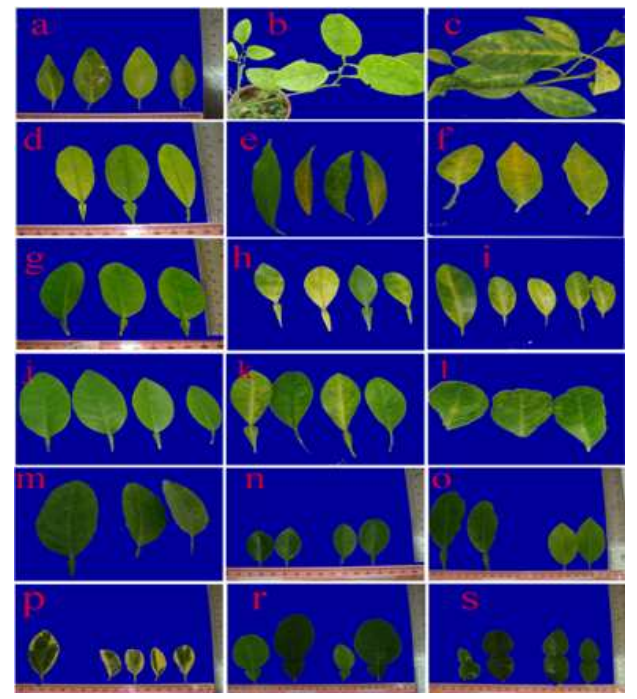

Fig. 1: Symptoms of HLB observed on different citrus species six months after graft inoculation; (a): C. reticulate; (b): C. reshni cv. Cleopatra; (c): C. sinensis, (d): C. macrophylla; (e): C. aurantifolia cv. Limau Nipis; (f): C. microcarpa cv. Limau Kasturi, (g): Fortunella sp.; (h): Citrus sp.; (i): Citrus sp., (j): Citrus sp.; (k): C. jambhiri; (l): C. medica; (m): Citrus sp.; (n): C. aurantifolia; (o): C. aurantium; (p): C. grandis; (r): C. hysterix; (s): Citrus sp. cv. Limau tembikai

Symptom expression of HLB: Symptoms expression is shown in Fig. 1. It was observed that $C$. grandis $\mathrm{cv}$. Limau Bali, C. hysterix cv. Limau purut and Citrus sp. cv. Limau tembikai showed no symptom of HLB after 6 months of inoculation and leaves remained green. Also no symptom of HLB occurred on $C$. aurantifolia cv. Mexican Lime and $C$. aurantium six months after graft inoculation. $C$. sinensis cv. Limau Lankat, $C$. reticulata cv. Limau Madu and C. reshni cv. Cleopatra showed severe symptoms of HLB at the sixth month after inoculation. C. reticulata showed midrib yellowing, yellowing and mild twig dieback six months after graft inoculation. C. sinensis and C. reshni cv. Cleopatra showed blotchy mottling and yellowing on leaf. On C. macrophylla fertilizer deficiency symptom was observed, but $C$. aurantifolia cv. Limau nipis showed mild blotchy mottling and midrib yellowing. C. microcarpa cv. Limau kasturi and Fortunella sp. were able to show blotchy mottling and mild yellowing on main veins. Mild midrib yellowing were observed on tow Citrus sp. (citrus natural biotype), C. jambhiri and $C$. medica, but on other citrus natural biotype and Citrus sp. cv. Limau Naga, mild blotchy mottling were observed.

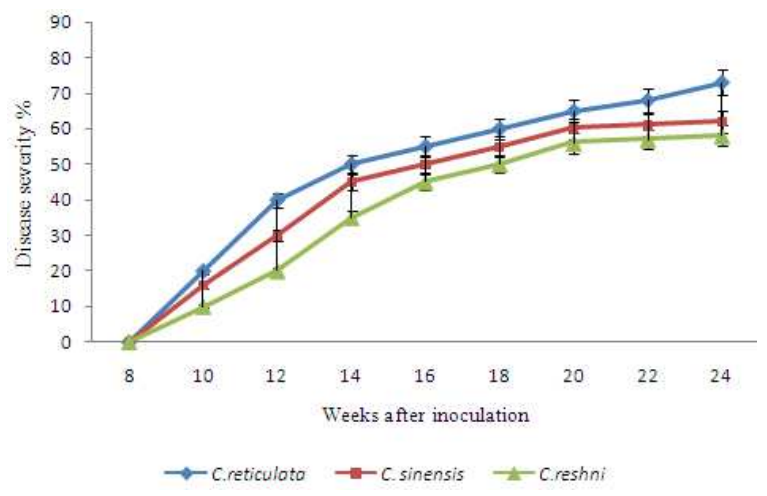

Fig. 2: Progress of HLB disease severity on severe group of citrus species

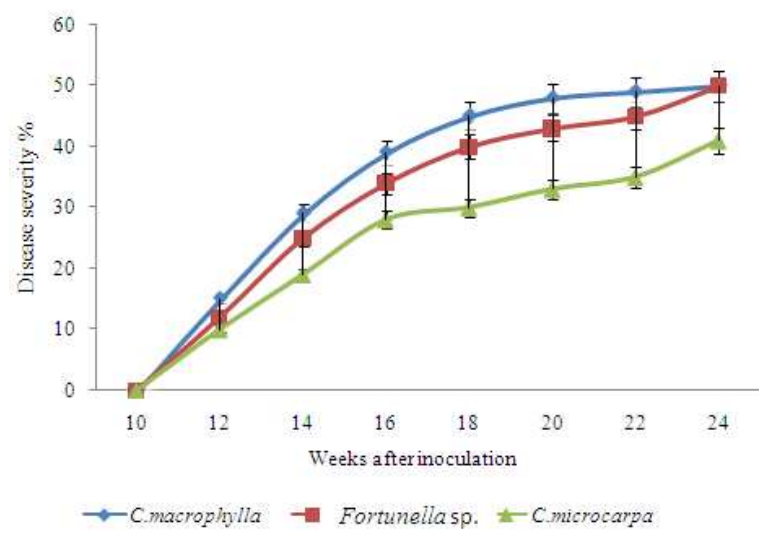

Fig. 3: Progress of HLB disease severity on moderate group of citrus species

Disease severity of HLB on citrus species: Disease severity was evaluated on individual inoculated seedlings. There were significant differences of disease severity observed among the 18 citrus species. $C$. reticulata, $C$. sinensis and $C$. reshni cv. Cleopatra showed high level of severity with value of $94.45-50 \%$ respectively. The symptom of HLB started to show 8 weeks after inoculation. This species showed severe symptom of HLB after 24 weeks (6 months) of inoculation (Fig. 2). Fortunella sp., C. mycrophylla and C. microcarpa showed moderate symptom of HLB with the value of $41-50 \%$ respectively.

This symptom started on week 10 after inoculation and showed severe symptom six months after inoculation (Fig. 3). C. medica, C. aurantifolia, Citrus sp. C. jambhiri and three citrus biotype (Citrus sp.) showed mild symptom of HLB with the value of 1725\% starting 14 weeks after inoculation and showed the highest symptom also 6 months after inoculation (Fig. 4). C. aurantifolia, C. aurantium, C. grandis and C. hysterix did not show symptom of the HLB 6 months after inoculation. 


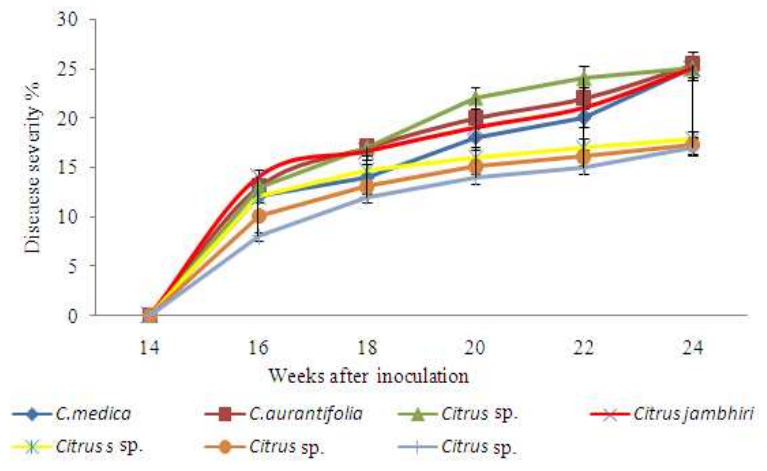

Fig. 4: Progress of HLB disease severity on mild group of citrus species

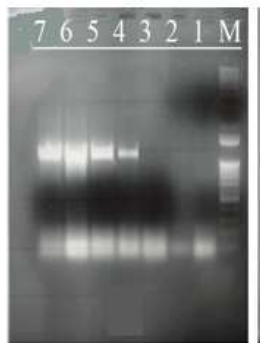

(a)

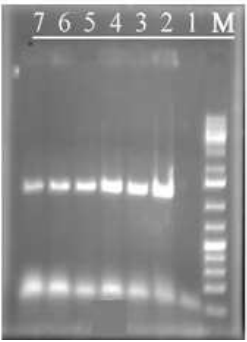

(b)

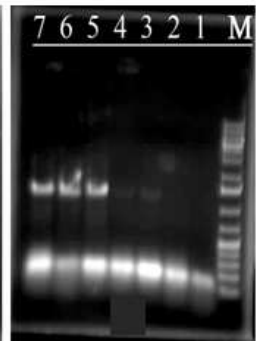

(c)
Fig. 5: 116s rDNA fragments with molecular weight of 1160 bp were successfully amplified from infected; (a): M. Marker (1): Water; (2): Citrus sp. cv. Limau Tembikai, (3): C. grandis cv. Limau Bali; (4): C. medica; (5): Citrus sp. cv. Limau Naga; (6): Citrus sp. (natural biotype); (7): Citrus sp. (natural biotype); (b): M. Marker (1): Water; (2): C. reticulate; (3): C.sinensis; (4): C. microcarpa cv. Limau Kasturi; (5): C. aurantifolia cv. Limau Nipis; (6): C. reshni cv. Cleopatra; (7): C. macrophylla; (c): M. Marker (1): Water; (2): C. hysterix cv. Limau Purut; (3): C. aurantifolia cv. Mexican Lime (4): C. aurantium; (5): Citrus sp. (natural biotype); (6): C. jambhiri; (7): Fortunella sp.

Detection of HLB pathogen on the species using PCR test: The amplified PCR product is $1160 \mathrm{bp}$ which is the targeted $16 \mathrm{~S}$ rDNA gene sequence region of the HLB pathogen amplified by the OI1 and OI2c primer sets. According to the result HLB was detected on fifteen citrus species (Table 3 and Fig. 5).According to the PCR test HLB was not present on 3 of the species including $C$. grandis, $C$. hysterix and Citrus sp.cv. Limau Tembiki (Fig. 5) and also the seedling did not show symptoms of HLB 6 months after graft inoculation. Results of PCR test show HLB was present on $C$. reticulata and $C$. sinensis (Fig. 5) and showed
Table 3: Percentage of positive PCR test of citrus species

\begin{tabular}{llc}
\hline Citrus species & Local name & Positive PCR test (\%) \\
\hline C. reticulata & Limau Madu & 100.00 \\
C. sinensis & Limau Lankat & 83.30 \\
C. reshni & Cleopatra & 66.67 \\
C. microcarpa & Limau kasturi & 66.67 \\
Citrus sp. & Limau Naga & 66.67 \\
C. macrophylla & Machrophylla & 66.67 \\
Fortunella sp. & Limau kasturi chini & 66.67 \\
C. aurantifolia & Limau Nipis & 50.00 \\
C. medica & Limau susu & 50.00 \\
C. jambhiri & Rough lemon & 50.00 \\
Citrus sp. & natural biotype & 33.34 \\
Citrus sp. & natural biotype & 33.34 \\
Citrus sp. & natural biotype & 33.34 \\
C. aurantium & Limau Samur & 16.00 \\
C. aurantifolia & Mexican lime & 16.00 \\
\hline
\end{tabular}

height infection with the value of $83.3-100 \%$ respectively among the citrus species. Results in Table 2 also showed that HLB was present on $C$. microcarpa cv. Limau Kasturi, C. reshni cv. Cleopatra, Citrus sp. cv. Limau Naga, C. macrophylla and Fortunella sp. (Fig. 5) and infection rate were $66.67 \%$.

HLB was also detected on C.aurantifolia cv. Limau Nipis, C. medica and C. jambhiri. The results of PCR test (Table 3) has shown 50\% rate of infection. HLB was present on 3 Citrus sp (natural biotype) with $33.3 \%$ rate of infection. $C$. aurantifolia and C.aurantium showed lowest infection (16\% positive PCR test of each species), but on symptom expression these species did not show any symptom of HLB. However HLB was present on 15 citrus species which were tested in the experiment and HLB was not present on 3 species including $C$. grandis, $C$. hysterix and Citrus sp. cv. Limau Tembikai. PCR is certainly a very effective, simple and sensitive tool for HLB detection. However, Candidatus Liberibacter is very low in concentration and unevenly distributed in its natural hosts.

\section{DISCUSSION}

Transmission of citrus greening occurs primarily via infective citrus psyllids, grafting and it is transmissible experimentally through dodder. However psyllid species feed and survive on citrus and citrus relatives. The side grafting method was chosen to transmit the HLB on species on high rate of inoculation. This study demonstrated high infection of HLB using grafting method. The scion used for grafting on these rootstocks grew and was normal growing development. C. reticulata and Limau Tembikai were less compatible with infected scion and the growth was disrupted. In this case scion survived and grew 3-5 cm after 6 months and the success rate of grafting was $35 \%$. When the 
scion and rootstock are from the same species grafting was be high successful. A successful graft union depends on good contact between the cambium of the rootstock with the cambium of the scion. The bacteria can be transmitted in orchards or nurseries by grafting and experimentally by several species of dodder (Cuscuta spp. $)^{[19]}$. Reduction rate of total dry weight, plant height and stem diameters on seedlings which showed severe symptoms of HLB were higher than the species which showed less HLB symptom, tolerant or resistance species too. Because the seedlings infected with HLB are usually stunted and it will be unproductive 4-5 years after planting. The infected seedlings to HLB was showing low rate of growing. Ahmad evaluated the effects of HLB infection on growth performance on C.reticulata based on the percentage reduction rate of total biomass and plant height. It was observed that high reduction rate of total biomass and plant height with the value of $56.2 \%$ and $39.4 \%$ respectively on infected honey mandarin ${ }^{[2]}$. Citrus species was showing different symptom of the HLB. Seedlings which become infected by HLB usually developed one or more yellow shoots. Leaves become thicker, with enlarged and corky veins and green areas are lacking. In later stages, zinc-like deficiency symptoms developed, followed by leaf drop and twig dieback ${ }^{[14]}$. Ahmad was not able to detect HLB on $C$. grandis in green house after six months of infection $^{[2]}$. These results also agree with the results which were reported by Manicom and Vuuren ${ }^{[16]}$, where they reported HLB symptoms on $C$. reticulata and C.sinensis (sweet orange) are more severe but lemon and grapefruits are tolerant. They also reported that $C$. aurantifolia and $C$. grandis are more tolerant to HLB. Some species and cultivars of citrus are somewhat tolerant to HLB. Most of the sweet orange trees became infected with the HLB pathogen and subsequently declined, while grapefruit was more tolerant $^{[15]}$. In general, sweet oranges, mandarins and tangelos are most susceptible, grapefruit and lemon are more resistant and limes, Poncirus trifoliate and citranges are the most tolerant ${ }^{[17]}$. Ahmad in Malaysia also reported that no HLB symptoms were observed on pummelo but C. reticulata cv. Honey Mandarin, C. madurensis cv. Calamondin and $C$. aurantium show severity with value of $75 \%, 65 \%$ and $50 \%$ respectively, but he transferred HLB pathogen to that species using Diaphorina citri vector ${ }^{[3]}$. Infected orange (C. sinensis), mandarin $(C$. reticulata) and tangelo (C. reticulata $\mathrm{x}$ $C$. paradise) produce the most severe symptoms and infected trees die within 3-5 years ${ }^{[18]}$. PCR test on this study also demonstrated that HLB was absent on C.grandis, C.hysterix, Citrus sp. cv. limau Tembiki.
These species were shown a normal growing during six months after inoculation. PCR is certainly a very effective, simple and sensitive tool for HLB detection. However, Candidatus Liberibacter is very low in concentration and unevenly distributed in its natural hosts. The PCR based assay detected almost all Asian HLB strain collected from different countries in Asia such as Malaysia ${ }^{[13]}$. Based on this study, it can be concluded that HLB can be identified on fifteen citrus species six months after graft infection. The species that were infected include: $C$. reticulata, $C$. sinensis, C. reshni cv. Cleopatra, C.microcarpa, C. medica, Citrus sp. (Natural Biotype), Citrus sp. (natural biotype), Citrus sp. cv. Limau Naga,Citrus sp. (natural biotype), C. jambhiri, Fortunella sp., C. aurantifolia and $C$. aurantium. But symptom expression and severity of HLB were different between species. However, C.grandis cv. Limau Bali, C. hysterix cv. Limau Purut Citrus sp. cv. Limau Tembiki showed negative reaction of HLB by PCR test and on these species no symptom showed six months after graft inoculation. According this study $C$. aurantifolia and C. aurantium was without symptom and showed $16 \%$ positive of HLB. However according to this study citrus species could be categorized as severe, moderate, mild, tolerant and resistant. Severe citrus species on HLB include C.reticulata, C. sinensis, C. reshni cv. Cleopatra. Moderate species include Fortunella sp., C.macrophylla and C. microcarpa cv. Kasturi. Mild species include C. medica, C. aurantifolia cv. Limau Nipis, Citrus sp. (natural biotype) and $C$. jambhiri. Tolerant species include $C$. aurantium and C.aurantifolia. Finally, resistant species include $C$. grandis, $C$. hysterix and Citrus sp. cv. Limau Tembikai. Ahmad used graft and insect vector to transmit HLB to evaluate citrus species against HLB. He reported that jasmine orange and pummelo were resistant to infection and no HLB symptom was observed even 6 months after inoculation. HLB isolate was also not detected in leaf tissue by PCR test ${ }^{[2]}$.

\section{REFERENCES}

1. FAO., 2003. Food and fertilizer technology centre for the Asian and pacific region, citrus greening and virus diseases of citrus, 2003-06-01. http://www.agnet.org/library/ac/2002d/

2. Khirolmazmi Ahmad, K.S., H. Habibuddin, J. Kadir and S.O.S. Rastan, 2008. Occurrence and spread of candiidatus liberibacter asiaticus, the causal agent of huanglongbing disease of citrus in Malaysia. Res. J. Agric. Biol. Sci., 4: 103-111. http://www.insinet.net/rjabs/2008/103-111.pdf 
3. Lim, W.H., O.M. Shamsudin and W. Kow, 1990. Citrus greening disease in Malaysia. In Rehabilitation of citrus industry in the Asia Pacific region. Proceeding of Asia Pacific International Conference on Citriculture, Feb. 4-10, Chiang Mai, Thailand, pp: 100-105.

4. Le Roux, H.F., S.P. van Vuuren, M.C. Pretorius and C.H. Buitendag, 2006. Management of huanglongbing in South Africa. Proceeding of the Workshop on Huanglongbing-Greening International, July 16-20, Ribeirão, Brazil, pp: 5-9.

5. Timmer, L.W. and S.M. Garnsey, 2003. Diseases of Citrus. In: Diseases of Tropical Fruit Crops, Ploetz, R.C. (Ed.). Tropical Research and Education Center, University of Florida, Hmestead, Florida, USA., pp: 544.

6. Azizah, M.J. and C. Zazali, 2005. Status kemerebakan dan impak Penyakit Greening Limau terhadap industry limau di Malaysia, in Jabatan Pertanian Malaysia. Bengkel Kebangsaan Pengurusan Penyakit Greening Limau.

7. Garnier, M. and J.M. Bove, 1983. Transmission of the organism associated with the citrus greening disease from sweet orange to periwinkle by dodder. Phytopathology, 73: 1358-1363. DOI: 10.1094/Phyto-73-1358

8. Jagoueix, S., J.M. Bove and M. Garnier, 1994. The phloem-limited bacterium of greening disease of citrus is a member of the subdivision of the Proteobacteria. Int. J. Syst. Bacteriol., 44: 379-386.

9. Jagoueix, S., J.M. Bové and M. Garnier, 1996. PCR detection of the two «Candidatus» liberobacter species associated with greening disease of citrus. Mol. Cell. Probes, 10: 43-50.

DOI: $10.1006 / \mathrm{mcpr} .1996 .0006$

10. Hung, T.H., M.L. $\mathrm{Wu}$ and H.J. Su, 2000. Identification of alternative hosts of the fastidious bacterium causing citrus greening disease. J. Phytopathol., $\quad$ 148: 321-326. http://wiley.com/10.1046/j.1439-0434.2000.00506.x

11. Bowen, K.L., 2004. Plant Disease Epidemiology. In: Plant Pathology, Concepts and Laboratory Exercises, Trigiano, M.T.W.R.N. and A.S. Windham (Ed.). CRC Press, New York, USA., ISBN: 9781420046694, pp: 576.
12. Kranzm, J., 1988. Measuring Plant Disease. In: Experimental Techniques in Plant Disease Epidemiology, Rotem, J.K.A.J. (Ed.). Springer Verlag, Berlin, Heidelberg, New York, pp: 35-50.

13. Hung, T.H., M.L. Wu and S.J. Hong, 1999. Development of rapid method for the diagnosis of citrus greening disease using polymerase chain reaction. J. Phytopathol., 147: 599-604. http://www3.interscience.wiley.com/journal/11904 5384/abstract?CRETRY=1\&SRETRY

14. Hung, T.H., S.C. Hung, C.N. Chen, M.H. Hsu and H.J. Su, 2004. Detection by PCR of candidatus liberibacter asiaticus, the bacterium causing citrus huanglongbing in vector psyllids: Application to the study of vector-pathogen relationships. Plant Pathol., 53: $\quad 96 . \quad$ DOI: $10.1111 / \mathrm{j} .1365-$ 3059.2004.00948.x

15. Halbert, S.E. and K.L. Manjunath, 2004. Asian citrus psyllids (Sternorrhyncha: Psyllidae) and greening disease in citrus: A literature review and assessment of risk in Florida. Florida Entomol., 87: 330-354. http://www.fcla.edu/FlaEnt/fe87p330.pdf

16. Manicom, B.Q. and S.P. Van Vuuren, 1990. Symptoms of greening disease with special emphasis on African greening. Proceeding of the 4th International Asia-Pacific Conference Citrus Rehabilitation, (IAPCCR'90), Chang Mai, Thailand, pp: 127-131.

17. Koizumi, M.P., M.G. Linwattana and T. Kaisuwan, 1997. Epidemiological aspects of citrus huanglongbin (Greening) disease in Thailand. JARQ., 31: 205-211.

18. Su, H.J. and S.C. Chang, 1976. The response of the likubin pathogen to antibiotics and heat therapy. Proceeding of the 7th Conference International Organization Citrus Virology, (CIOCV'76), University of California, California, pp: 27-34.

19. Floyd, J.A.C.K., 2008. New pest response guidelines: Citrus greening disease. USDAAPHIS-PPQ-Emergency and Domestic Programs, Riverdale, Maryland. http://www.aphis.usda.gov/plant_health/plant_pest _info/citrus_greening/downloads/pdf_files/cg 